
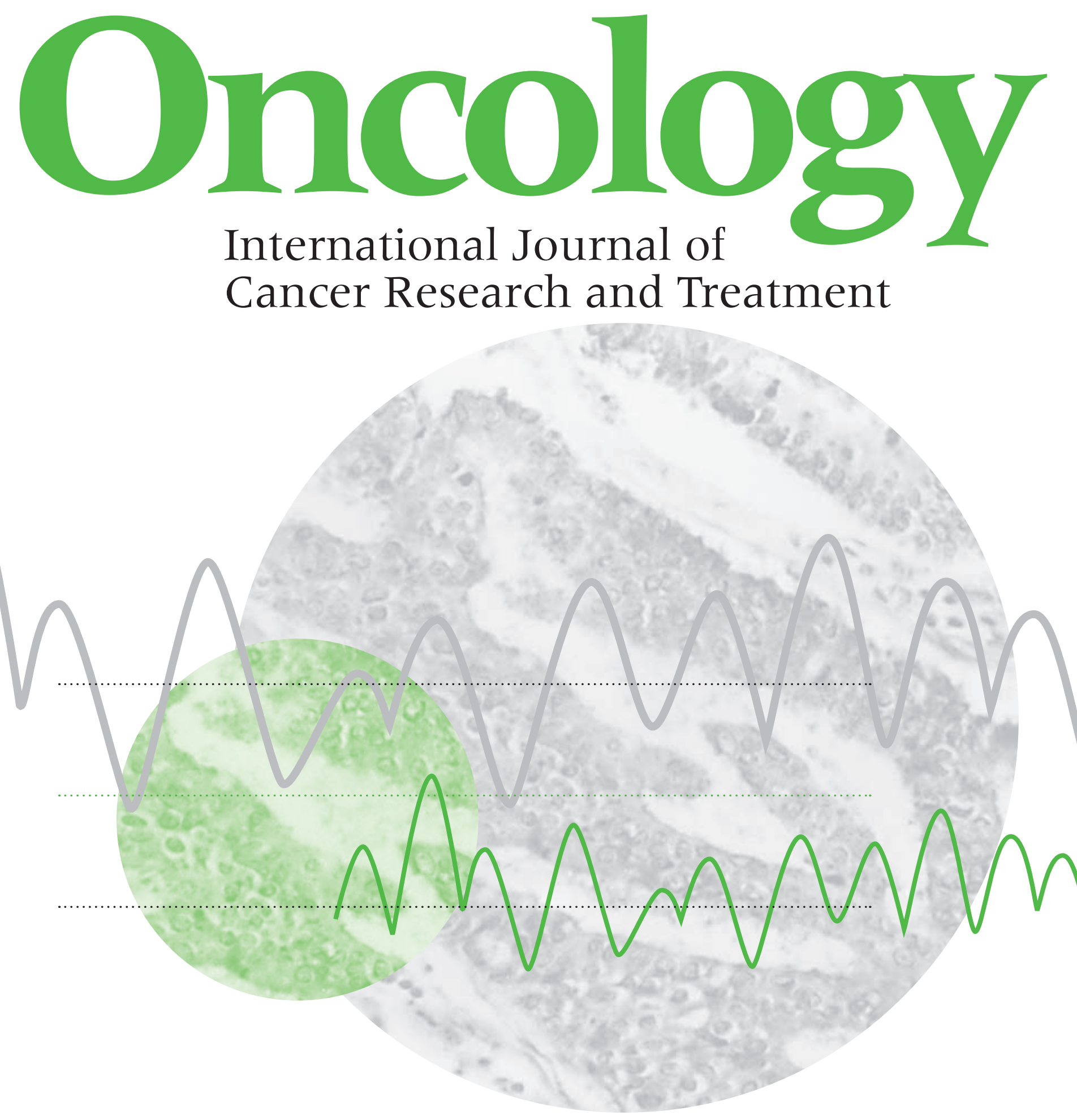


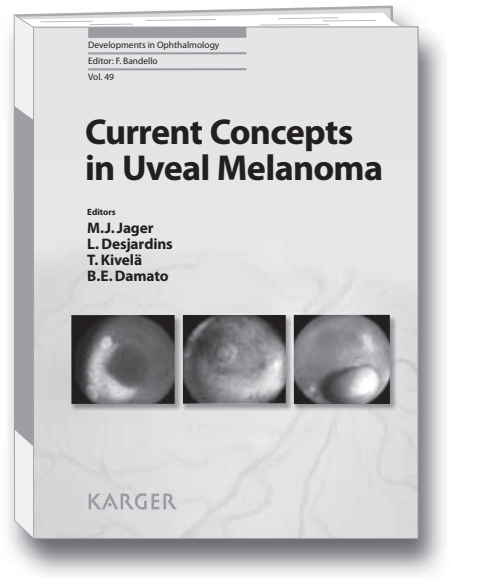

Uveal melanoma is an aggressive form of cancer that can involve the iris, the ciliary body, and/or the choroid, which is the main location of this tumor. Patients often wish to be informed about treatment choices and the results of different approaches. Important current clinical questions are whether a biopsy should be taken of choroidal melanomas, what should be done with this biopsy, and whether high-risk patients should be screened regularly.

This volume describes the clinical characteristics of uveal melanoma along with the different current techniques available for treatment, such as radioactive plaque treatment, proton beam therapy, and local tumor resection. Furthermore, techniques for taking biopsies and characterizing biopsy material are demonstrated. Future therapies such as anti-VEGF treatment and options for the treatment of metastases are also discussed.

Residents with an interest in ocular oncology, ophthalmologists or physicians dealing with uveal melanoma, as well as patients wishing to know more about this malignancy will find a topical update on uveal melanoma in this publication.

\section{Current Concepts in Uveal Melanoma}

\section{Editors}

\author{
Martine J. Jager \\ Laurence Desjardins \\ Tero Kivelä \\ Bertil E. Damato
}

\section{Contents}

Preface: Jager, M.J.; Desjardins, L.; Kivelä, T.; Damato, B.E.

Diagnosis of Uveal Melanoma: Kivelä, $\boldsymbol{T}$.

Treatment Selection for Uveal Melanoma: Damato, B.E.

Ruthenium-106 Brachytherapy: Pe'er, $J$.

Treatment of Uveal Melanoma by

Accelerated Proton Beam: Desjardins, L.;

Lumbroso-Le Rouic, L.; Levy-Gabriel, C.;

Cassoux, N.; Dendale, R.; Mazal, A.;

Delacroix, S.; Sastre, $X_{\text {.; }}$ Plancher, C.;

Asselain, $B$.

Stereotactic Photon Beam Irradiation of

Uveal Melanoma: Zehetmayer, $\boldsymbol{M}$.

Local Resection of Uveal Melanoma:

Damato, B.E.

Biopsies in Uveal Melanoma: Midena, E.;

Parrozzani, $R$.
Analysis of Intraocular Biopsies: Coupland, S.E. Antiangiogenic Therapy in Uveal Melanoma: el Filali, M.; van der Velden, P.A.; Luyten, G.P.M.; Jager, M.J.

Immunotherapy of Uveal Melanoma:

Bosch, J.J.

Genetic Determinants of Uveal Melanoma: Couturier, J.; Saule, $S$.

Therapeutic Options in Metastatic Uveal Melanoma: Mariani, $\boldsymbol{P}_{\text {.; }}$ Servois, $\boldsymbol{V}_{\text {.; }}$ Piperno-Neumann, $\mathrm{S}$.

www.karger.com/deoph

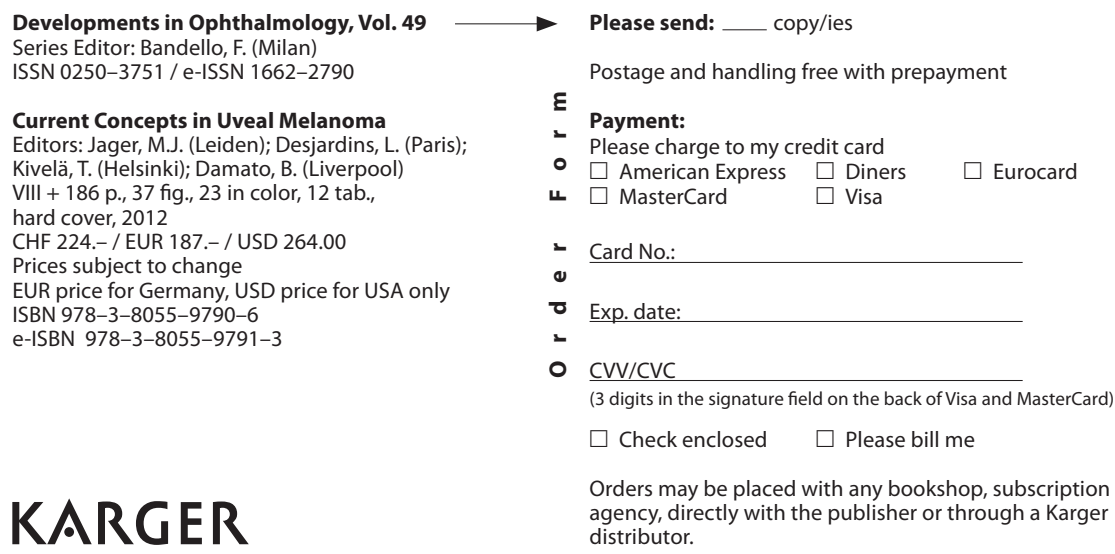

copy/ies

$\varepsilon$ Postage and handling free with prepayment

Payment

Please charge to my credit card

- $\square$ American Express $\square$ Diners $\square$ Eurocard

ᄂ $\square$ MasterCard $\square$ Visa

- Card No

(

ర Exp. date:

$=$

- CVV/CVC

(3 digits in the signature field on the back of Visa and MasterCard)

$\square$ Check enclosed $\quad \square$ Please bill me

Orders may be placed with any bookshop, subscription agency, directly with the publisher or through a Karger distributor.

Fax: +41613061234

S. Karger AG, P.O. Box, CH-4009 Basel (Switzerland) E-Mail orders@karger.ch,www.karger.com

Name/Address: 


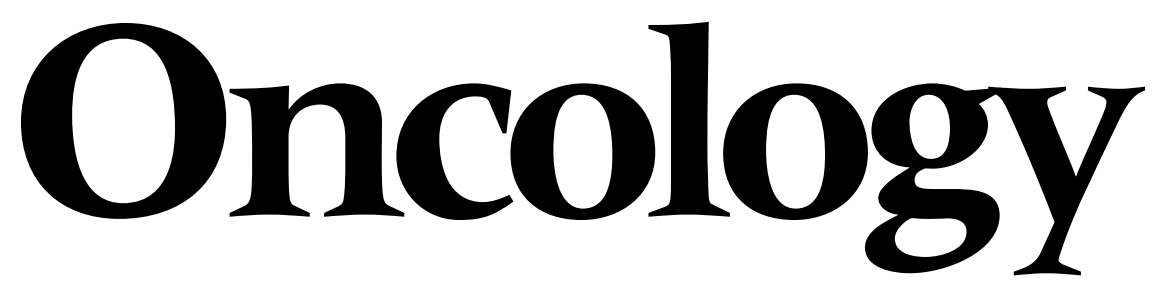

International Journal of Cancer Research and Treatment

Founded 1948 as 'Oncologia' by H.R. Schinz

Continued by V. Richards (1967-1975), H. Wrba (1976-1992), P.P. Carbone (1993-2002),

D.L. Trump (2002-2007)

\section{Editor-in-Chief}

M. Markman, Philadelphia, Pa.

\section{Associate Editor}

P. Dufour, Strasbourg

Regional Editor Japan

O. Hino, Tokyo

\section{Editorial Board}

A.B. Benson, Chicago, Ill. A. Chang, Singapore

A.L. Cheng, Taipei

J.F. Cleary, Madison, Wisc.

M.S. Ernstoff, Lebanon, N.H.

M. Fakih, Ann Arbor, Mich.

J.J. Grau, Barcelona

H. Gronemeyer, Illkirch

D.F. Hayes, Ann Arbor, Mich.

C.S. Johnson, Buffalo, N.Y.

M.J. Kelley, Durham, N.C.

P.J. Loehrer, Indianapolis, Ind.

J.R. Marshall, Buffalo, N.Y.

S. Monfardini, Milan

R. Nagler, Haifa

R. Ohno, Nagoya

B. Pestalozzi, Zurich

H.M. Pinedo, Amsterdam

E.A. Repasky, Buffalo, N.Y.

A. Semczuk, Lublin

C.N. Sternberg, Rome

R. Stupp, Lausanne

M.S. Tallman, Chicago, Ill.

S. Tanaka, Hiroshima

M. Tian, Houston, Tex.

D.L. Trump, Buffalo, N.Y.

T. Wiegel, Ulm

W. Yasui, Hiroshima

H. Zhang, Hangzhou City 


\section{Submission}

Original papers and reviews written in English are considered for publication. Manuscripts should be submitted to 'Oncology' online. For specific instructions on how to prepare a manuscript for submission, you are encouraged to view the guidelines at www. karger.com/ocl, where you will also find a link to the Submission Website. Names, postal and e-mail addresses of at least four experts in the appropriate area of research must accompany each manuscript. Selected scientists will be invited to act as referees. Referees suggested should not be from the same institution as the author and should have expert knowledge of the subject. Should you have any problems with your submission, please contact:

Dr. M. Markman
S. Karger AG
Editorial Office 'Oncology'
P.O. Box
CH-4009 Basel (Switzerland)
Tel. +41 613061359
Fax +41 613061434
E-Mail ocl@karger.ch

Mailing address for courier deliveries only: Allschwilerstr. 10

CH-4055 Basel (Switzerland)

\section{Conditions}

All manuscripts are subject to editorial review. Manuscripts are received with the explicit understanding that they are not under simultaneous consideration by any other publication. The editors reserve the right to improve style and, if necessary, return the manuscript for rewriting to the author. Submission of an article for publication implies the transfer of the copyright from the author to the publisher upon acceptance. Accepted papers become the permanent property of 'Oncology' and may not be reproduced by any means, in whole or in part, without the written consent of the publisher. It is the author's responsibility to obtain permission to reproduce illustrations, tables, etc. from other publications.

All manuscripts originating from non-English speaking countries must be revised by a professional linguistic reviewer and it must be evident from the covering letter that this has been done.

The editor reserves the right to reject papers based on priorities and space availability in the journal.

\section{Conflicts of Interest}

Authors are required to disclose any sponsorship or funding arrangements relating to their research and all authors should disclose any possible conflicts of interest. Conflict of interest statements will be published at the end of the text of the article.

\section{Ethical and Legal Prerequisites}

Manuscripts involving examinations of human subjects must include a statement that the trial protocol has been approved by an ethical committee and thus meets the standards of the Declaration of Helsinki in its revised version of 1975 and its amendments of 1983, 1989, and 1996 [JAMA 1997;277:925-926]. Accordingly, the subject's informed consent has to be mentioned in the manuscript. Information suitable to reveal the subject's identity is to be avoided.

\section{Categories of Manuscripts}

Reviews are comprehensive, state-of-the-art analyses and investigations of important clinical problems. Reviews must include a critical discussion of the reported data and give a clear conclusion with the potential impacts on the standard of care. Reviews may be invited by the Editor, or they may be unsolicited submissions. Reviews are not subject to page charges. The maximum length of manuscripts in this category will be 5,000 words for text and tables (a table $=250$ words per page), with a maximum of 5 tables and 50 references.

Clinical Studies and Clinical Translational Research Articles are full-length research papers which will be considered for the journal. These articles cover topics relevant to clinical and translational studies in all oncological fields. Note that manuscripts presenting laboratory-based research efforts must address a clinically relevant issue (Translational Research).

Short Communications will focus on descriptions of important toxicities of novel therapies and highly unique oncology-related medical management issues. The maximum length of manuscripts in this category will be 1,000 words.

Clinical Trial Notes are designed for brief discussions of clinical trials, with a particular focus on phase 1 , phase $1 / 2$, and phase 2 studies. Priority in this section will not be for studies with a 'positive result', but rather for well-conceived and conducted clinical research efforts. The maximum length of manuscripts submitted in this category will be 1,500 words, with a maximum of 2 tables and 1 figure. The paper should be divided into four sections: Introduction, Methods, Results, Discussion. Note that all manuscripts submitted in this category will undergo rapid review for acceptance or rejection.

Reducing the Worldwide Burden of Cancer are country reports describing a variety of regional, national or international efforts that focus on the unique aspects of the epidemiology of cancer, and the delivery of educational messages, preventive services, and oncology-related care within the developing world. Papers submitted for this section benefit from a higher quota of free pages. There are no page charges for papers of 8 or fewer printed pages. Each additional complete or partial page is charged to the author at CHF 325.00.

Editorials provide comments on papers published in Oncology. They are usually invited by the Editor.

\section{Arrangement}

Title page: The first page of each paper should indicate the title, the authors' names, the institute where the work was conducted, and a short title for use as running head.

Full address: The exact postal address of the corresponding author complete with postal code must be given at the bottom of the title page. Please also supply phone and fax numbers, as well as e-mail address.

Key words: Please supply 3-10 key words in English that reflect the content of the paper.

Abstract: Papers submitted to the sections Reviews, Clinical Studies, Clinical Translational Research Articles, Clinical Trial Notes and Reducing the World- wide Burden of Cancer need an abstract of up to 200 words. Abstracts are recommended, but optional, for Short Communications and Editorials. Abstracts of papers submitted for publication that have clinical implications using human materials should be structured with subheadings as follows: Objective(s), Methods, Results, Conclusion(s).

Footnotes: Avoid footnotes. When essential, they are numbered consecutively and typed at the foot of the appropriate page.

Tables and illustrations: Tables and illustrations (both numbered in Arabic numerals) should be prepared on separate pages. Tables require a heading and figures a legend, also prepared on a separate page. Due to technical reasons, figures with a screen background should not be submitted. When possible, group several illustrations in one block for reproduction ( $\max$. size $180 \times 223 \mathrm{~mm}$ ) or provide crop marks. Each illustration must be labelled with its number and the first author's name. $\mathrm{B} / \mathrm{w}$ half-tone and color illustrations must have a final resolution of $300 \mathrm{dpi}$ after scaling, line drawings one of $800-1,200$ dpi. Figure files must not be embedded in a document file but submitted separately (see detailed instructions on the Submission Website at www.karger.com/ocl).

\section{Color illustrations}

Online edition: Color illustrations are reproduced free of charge. In the print version, the illustrations are reproduced in black and white. Please avoid referring to the colors in the text and figure legends. Print edition: Up to 6 color illustrations per page can be integrated within the text at CHF 800.- per page.

\section{References}

In the text identify references by Arabic numerals [in square brackets]. Material submitted for publication but not yet accepted should be noted as 'unpublished data' and not be included in the reference list. The list of references should include only those publications which are cited in the text. Do not alphabetize; number references in the order in which they are first mentioned in the text. The surnames of the authors followed by initials should be given. There should be no punctuation other than a comma to separate the authors. Preferably, please cite all authors. Abbreviate journal names according to the Index Medicus system. Also see International Committee of Medical Journal Editors: Uniform requirements for manuscripts submitted to biomedical journals (www. icmje.org).

Examples

(a) Papers published in periodicals: Chatel J-M, Bernard H, Orson FM: Isolation and characterization of two complete Ara h 2 isoforms cDNA. Int Arch Allergy Immunol 2003;131:14-18.

(b) Papers published only with DOI numbers:

Theoharides TC, Boucher W, Spear K: Serum interleukin-6 reflects disease severity and osteoporosis in mastocytosis patients. Int Arch Allergy Immunol DOI: $10.1159 / 000063858$.

(c) Monographs: Matthews DE, Farewell VT: Using and Understanding Medical Statistics, ed 3, revised. Basel, Karger, 1996.0

(d) Edited books: Cochrane AL, Ricardo SD: Oxidant stress and regulation of chemokines in the develop-

\section{KARGER}

Fax +41 613061234

E-Mail karger@karger.ch

www.karger.com 
ment of renal interstitial fibrosis; in Razzaque MS, Taguchi T (eds): Renal Fibrosis. Contrib Nephrol. Basel, Karger, 2003, vol 139, pp 102-119.

Reference Management Software: Use of EndNote is recommended for easy management and formatting of citations and reference lists.

\section{Digital Object Identifier (DOI)}

S. Karger Publishers supports DOIs as unique identifiers for articles. A DOI number will be printed on the title page of each article. DOIs can be useful in the future for identifying and citing articles published online without volume or issue information. More information can be found at www.doi.org.

\section{Supplementary Material}

Supplementary material is restricted to additional data that are not necessary for the scientific integrity and conclusions of the paper. Please note that all supplementary files will undergo editorial review and should be submitted together with the original manuscript. The Editors reserve the right to limit the scope and length of the supplementary material. Supplementary material must meet production quality standards for Web publication without the need for any modification or editing. In general, supplementary files should not exceed $10 \mathrm{MB}$ in size. All figures and tables should have titles and legends and all files should be supplied separately and named clearly. Acceptable files and formats are: Word or PDF files,
Excel spreadsheets (only if the data cannot be converted properly to a PDF file), and video files (.mov, .avi, .mpeg).

\section{Author's Choice ${ }^{\mathrm{TM}}$}

Karger's Author's Choice ${ }^{\mathrm{TM}}$ service broadens the reach of your article and gives all users worldwide free and full access for reading, downloading and printing at www.karger.com. The option is available for a onetime fee of CHF 3000.-, which is a permissible cost in grant allocation. More information can be found at www.karger.com/authors_choice.

\section{NIH-Funded Research}

The U.S. National Institutes of Health (NIH) mandates under the NIH Public Access Policy that final, peer-reviewed manuscripts appear in its digital database within 12 months of the official publication date. As a service to authors, Karger submits the final version of your article on your behalf to PubMed Central. For those selecting our premium Author's Choice $^{\mathrm{TM}}$ service, we will send your article immediately upon publishing, accelerating the accessibility of your work without the usual embargo. More details on NIH's Public Access Policy is available at http:// publicaccess.nih.gov/policy.htm

\section{Self-Archiving}

Karger permits authors to archive their pre-prints (i.e. pre-refereeing) or post-prints (i.e. final draft post-ref- ereeing) on their personal or institution's servers, provided the following conditions are met: Articles may not be used for commercial purposes, must be linked to the publisher's version, and must acknowledge the publisher's copyright. Authors selecting Karger's Author's Choice ${ }^{\mathrm{TM}}$ feature, however, are also permitted to archive the final, published version of their article, which includes copyediting and design improvements as well as citation links.

\section{Page Charges}

There are no page charges for papers of 3 or fewer printed pages (including tables, illustrations and references). Each additional complete or partial page is charged to the author at CHF 325.-. The allotted size of a paper is equal to approx. 9 manuscript pages (including tables, illustrations and references).

\section{Proofs}

Unless indicated otherwise, proofs are sent to the corresponding author and should be returned with the least possible delay. Alterations other than the correction of printer's errors are charged to the author.

\section{Reprints}

Order forms and a price list are sent with the proofs. Orders submitted after the issue is printed are subject to considerably higher prices.

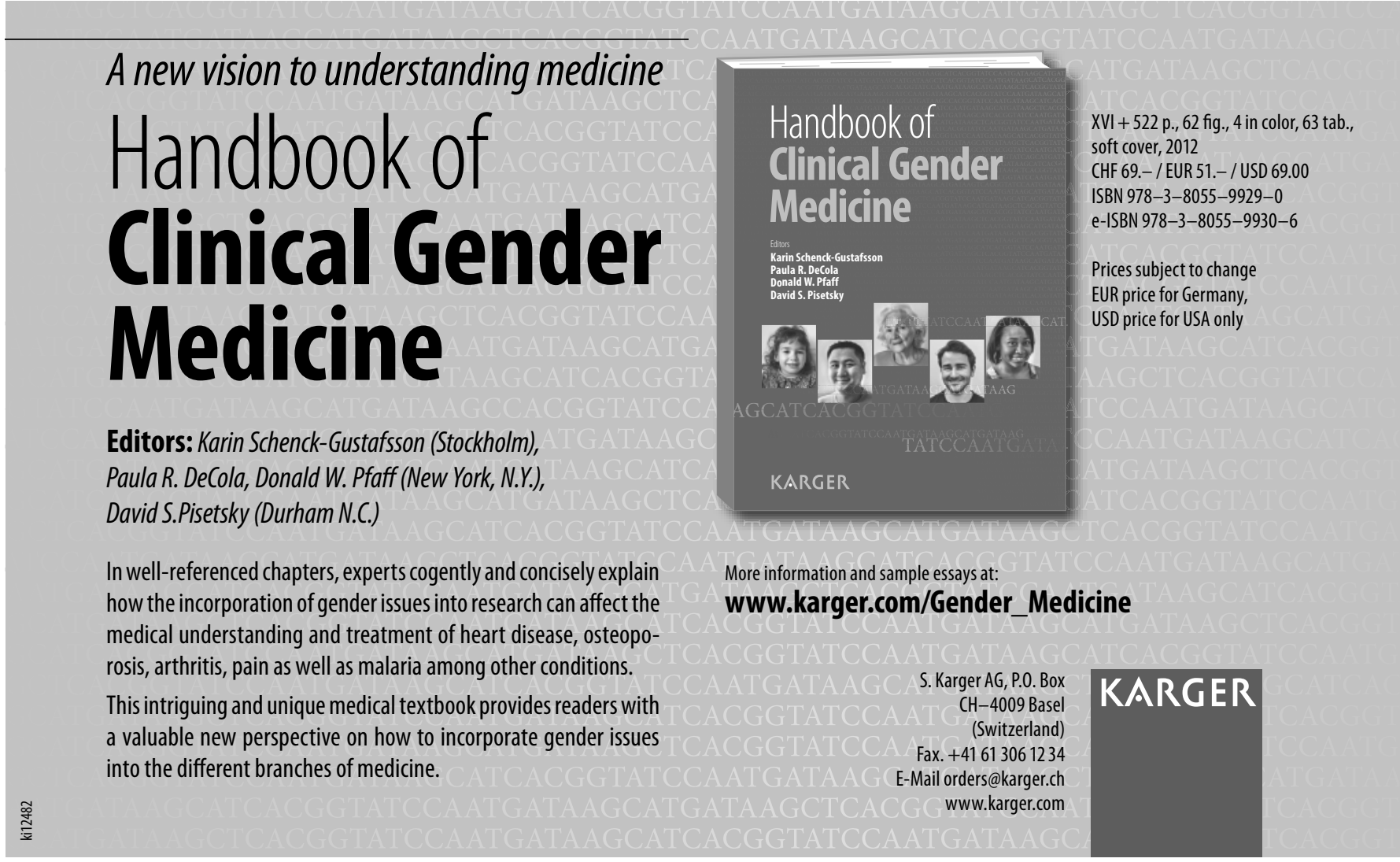

\section{KARGER}

Fax +4161306 1234

E-Mail karger@karger.ch

www.karger.com 


\section{Oncology}

ISSN Print Edition: 0030-2414

ISSN Online Edition: 1423-0232

Journal Homepage: www.karger.com/ocl

Publication Data: 'Oncology' is published 12 times a year. Volumes 84 and 85 , each with 6 issues, appear in 2013.

Copyright: (c) 2013 S. Karger AG, Basel (Switzerland). All rights reserved. No part of this publication may be translated into other languages, reproduced or utilized in any form or by any means, electronic or mechanical, including photocopying, recording, microcopying, or by any information storage and retrieval system, without permission in writing from the publisher or, in the case of photocopying, direct payment of a specified fee to the Copyright Clearance Center.

Disclaimer: The statements, opinions and data contained in this publication are solely those of the individual authors and contributors and not of the publisher and the editor(s). The appearance of advertisements in the journal is not a warranty, endorsement, or approval of the products or services advertised or of their effectiveness, quality or safety. The publisher and the editor(s) disclaim responsibility for any injury to persons or property resulting from any ideas, methods, instructions or products referred to in the content or advertisements.
Subscription Rates: Subscriptions run for a full calendar year. Prices are given per year. Personal subscription:

Print or Online

CHF 1622.-

EUR 1308.-

USD 1606.00

Print+Online combined CHF 1718.-

EUR 1386.-

USD 1702.00

postage and handling (added to print and print+online)

CHF 86.40 Europe, CHF 124.80 Overseas

EUR 67.20

USD 115.20

Institutional subscription:

Print or Online

Print+Online combined

CHF 3244.-

EUR 2616.-

CHF 3568.-

USD 3212.00

USD 3532.00

postage and handling (added to print and print+online)

CHF 108.- Europe, CHF 156.- Overseas

EUR 84.-

USD 144.00

Airmail surcharge: CHF 105.- / USD 99.00
Back Volumes and Single Issues: Information on availability and prices of single print issues and print or electronic back volumes can be obtained from Customer Service atservice@karger.ch.

Bibliographic Indices: This journal is regularly listed in bibliographic services, including Current Contents ${ }^{\circledR}$ and PubMed/MEDLINE.

Photocopying: This journal has been registered with the Copyright Clearance Center (CCC), as indicated by the code appearing on the first page of each article. For readers in the US, this code signals consent for copying of articles for personal or internal use, or for the personal or internal use of specific clients, provided that the stated fee is paid per copy directly to

Copyright Clearance Center Inc.

222 Rosewood Drive

Danvers, MA 01923 (USA)

A copy of the first page of the article must accompany payment. Consent does not extend to copying for general distribution, for promotion, for creating new works, or for resale. In these cases, specific written permission must be obtained from the copyright owner,

S. Karger AG, P.O. Box

CH-4009 Basel (Switzerland).
Subscription Orders:

Orders can be placed at agencies,
Ordion Orders:

bookstores, directly with the Publisher

\section{S. Karger AG}

Medical and Scientific Publishers

P.O. Box

CH-4009 Basel

Switzerland

(for courier services only:

Allschwilerstrasse 10

CH-4055 Basel)

$\mathrm{t}: \quad+41613061111$

f: +41613061234

e: karger@karger.ch

w: www.karger.com or further Karger offices

or representatives:

\section{Germany}

S. Karger GmbH

Postfach

79095 Freiburg

Deutschland

(Hausadresse: Wilhelmstrasse 20A,

79098 Freiburg)

t: +49761452070

f: +497614520714

e: information@karger.de

w: www.karger.de

\section{Japan}

Karger Japan, Inc.

Shiba Daimon Asahi Bldg. 2F

1-2-23 Shiba Daimon

Minato-ku

Tokyo 105-0012

Japan

t: +81364356242

f: +81364356244

e: publisher@karger.jp

w: www.karger.jp

Change of Address:

Both old and new address should be sent to the subscription source.

USA

S. Karger Publishers, Inc.

26 West Avon Road

P.O. Box 529

Unionville, CT 06085

USA

Toll free: +18008285479

t: +18606757834

f: +18606757302

e: karger@snet.net

France

Librairie Médi-Sciences Sarl

36, bd de Latour-Maubourg

75007 Paris

France

t: $+33(0) 145514258$

$\mathrm{t}: \quad+33(0) 145514258$
$\mathrm{f}: \quad+33(0) 145560780$

f: $+33(0) 145560780$
e: librairie@medi-sciences.fr

w: www.medi-sciences.fr

Gulf Council Countries, Iran,

Middle East, North Africa, Turkey

Trans Middle East International

Distribution Co. Ltd. (KaSha)

168 B, King Abdullah the 2nd Street

Daboog Building 2nd Floor

Daboog Area

P.O. Box 2376

Amman 11953

Jordan

t: +962 65153467

t: +96265153467

e: info@kasha.cc

w: www.KaShaonline.com
South East Asia, China and Taiwan Karger Regional Office (Malaysia) CEO Suite Kuala Lumpur Quill 7,27th Floor

Jalan Stesen Sentral 5

KL Sentral

Kuala Lumpur 50470

Malaysia

t: +60327766803

f: +60327766999

e: service@karger.cn; r.chew@karger.cn

\section{Karger China}

10th Floor, Twin Towers (East)

B12 Jianguomenwai Avenue

Beijing 100022

China

t: +861051235033

f: +861051235122

e: service@karger.cn; r.chew@karger.cn

w: www.karger.cn

India, Bangladesh, Sri Lanka

Medscience India

Plot No. 17, Yusuf Sarai Market

B.L. Glass Building, 2nd Floor

Sri Aurobindo Marg

New Delhi 110016

India

t: +911146029633

f: +911146029634

c: +919891052128

e: medsci.india@gmail.com

\section{KARGER}

Fax +41 613061234

E-Mail karger@karger.ch

www.karger.com
(C) 2013 S. Karger AG, Basel

The Guidelines for Authors are available at www.karger.com/ocl_Guidelines 


\section{Contents}

See the journal website for contents

KARGER Basel $\bullet$ Freiburg $\cdot$ Paris $\bullet$ London $\bullet$ New York $\cdot$ New Delhi $•$ Bangkok Beijing $\cdot$ Tokyo $\cdot$ Kuala Lumpur $\cdot$ Singapore $\bullet$ Sydney 


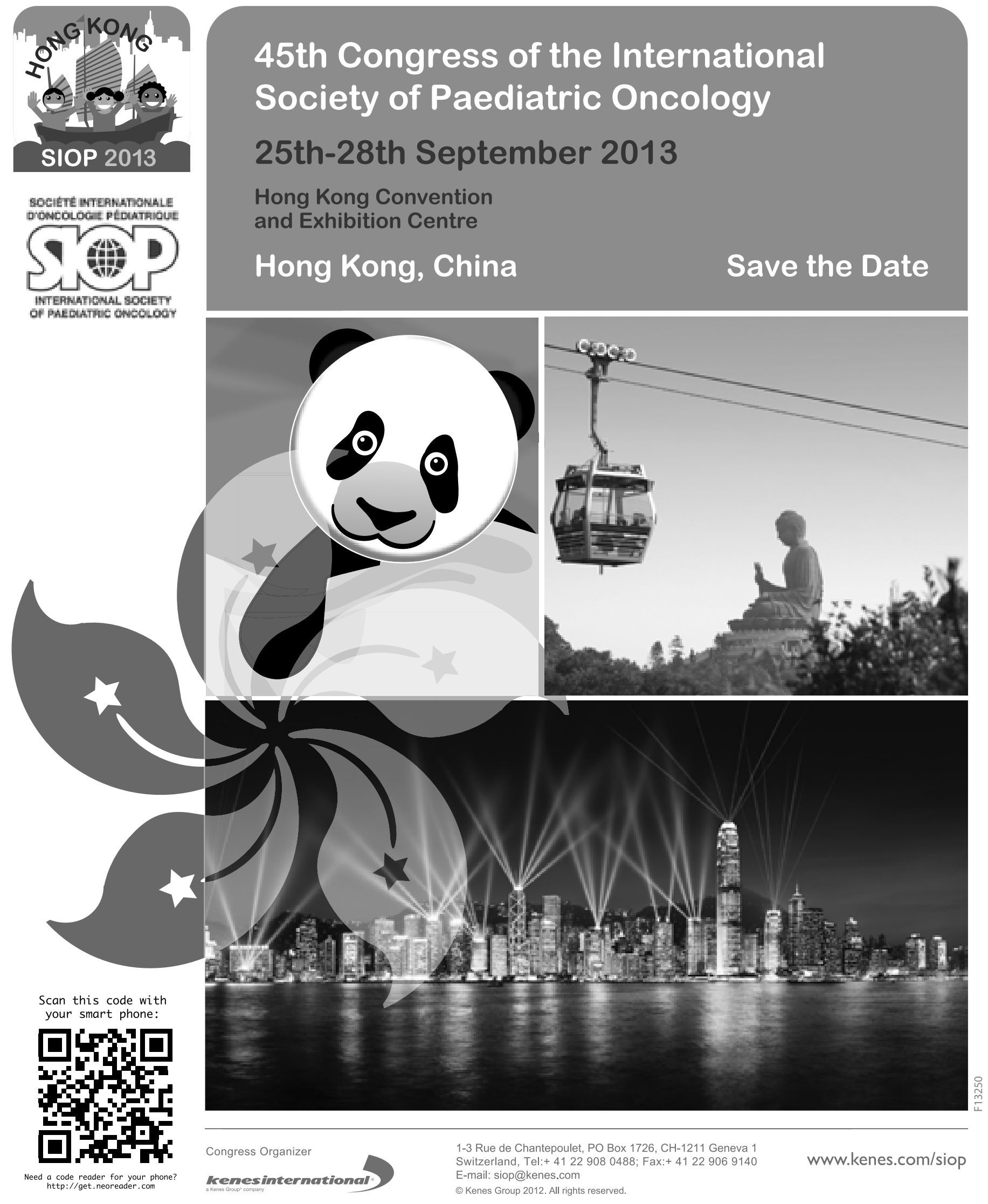




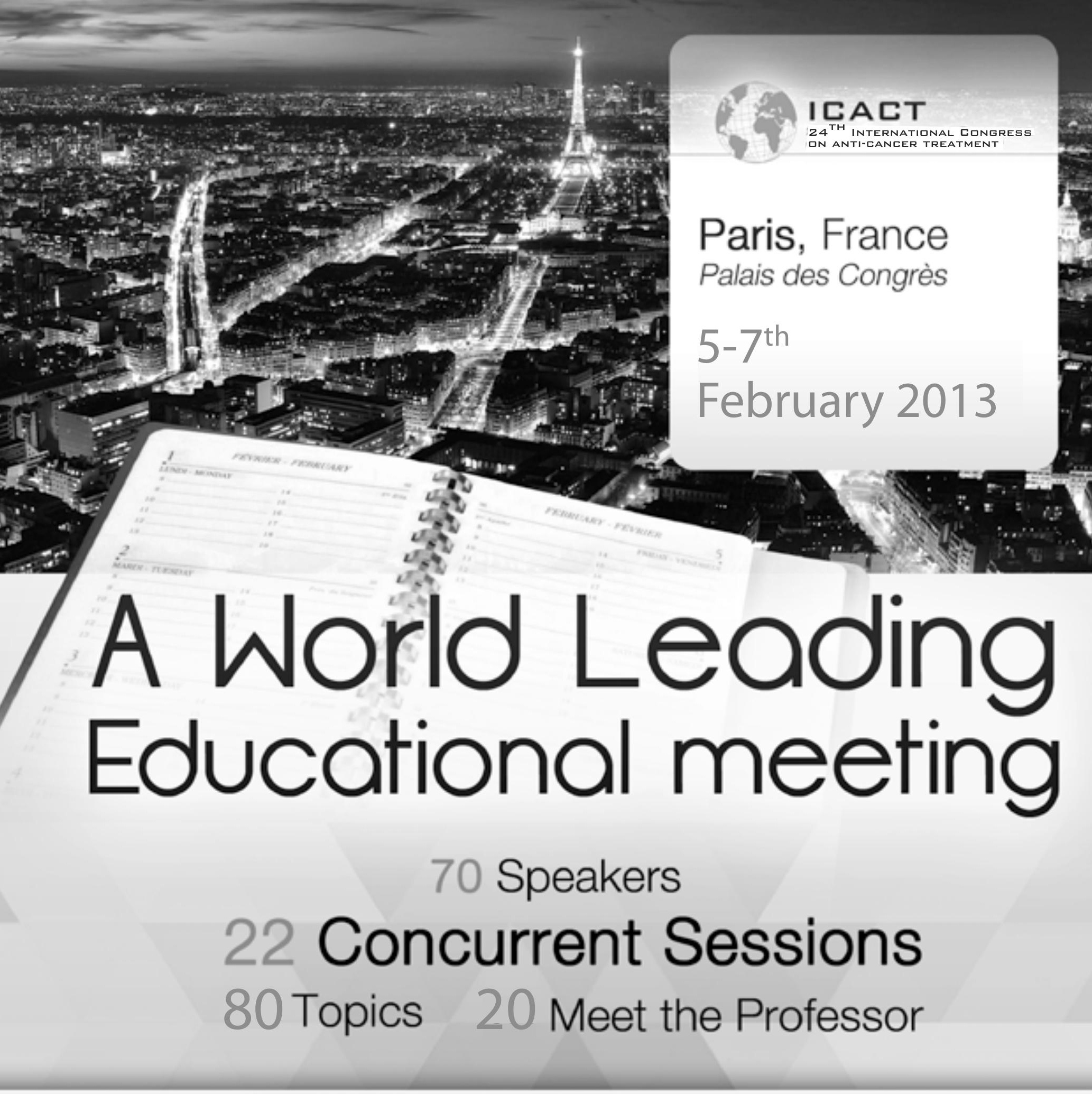

For further information, kindly visit www.icact.com or send us email via infos@im-events.com. We look foward to your participation in the $24^{\text {th }}$ International Congress on Anti-Cancer Treatment

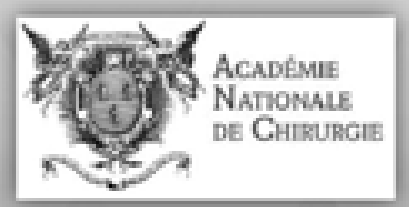




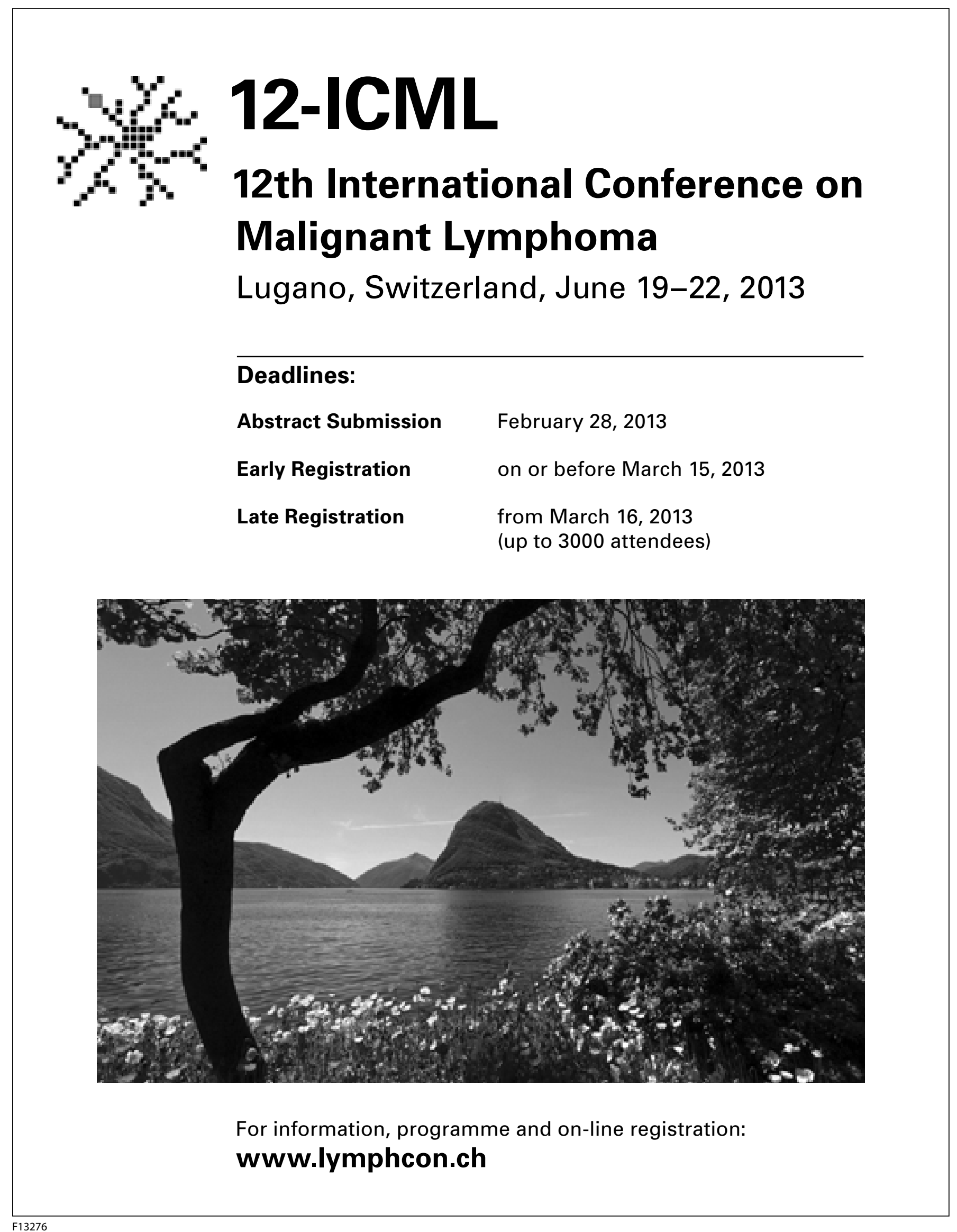




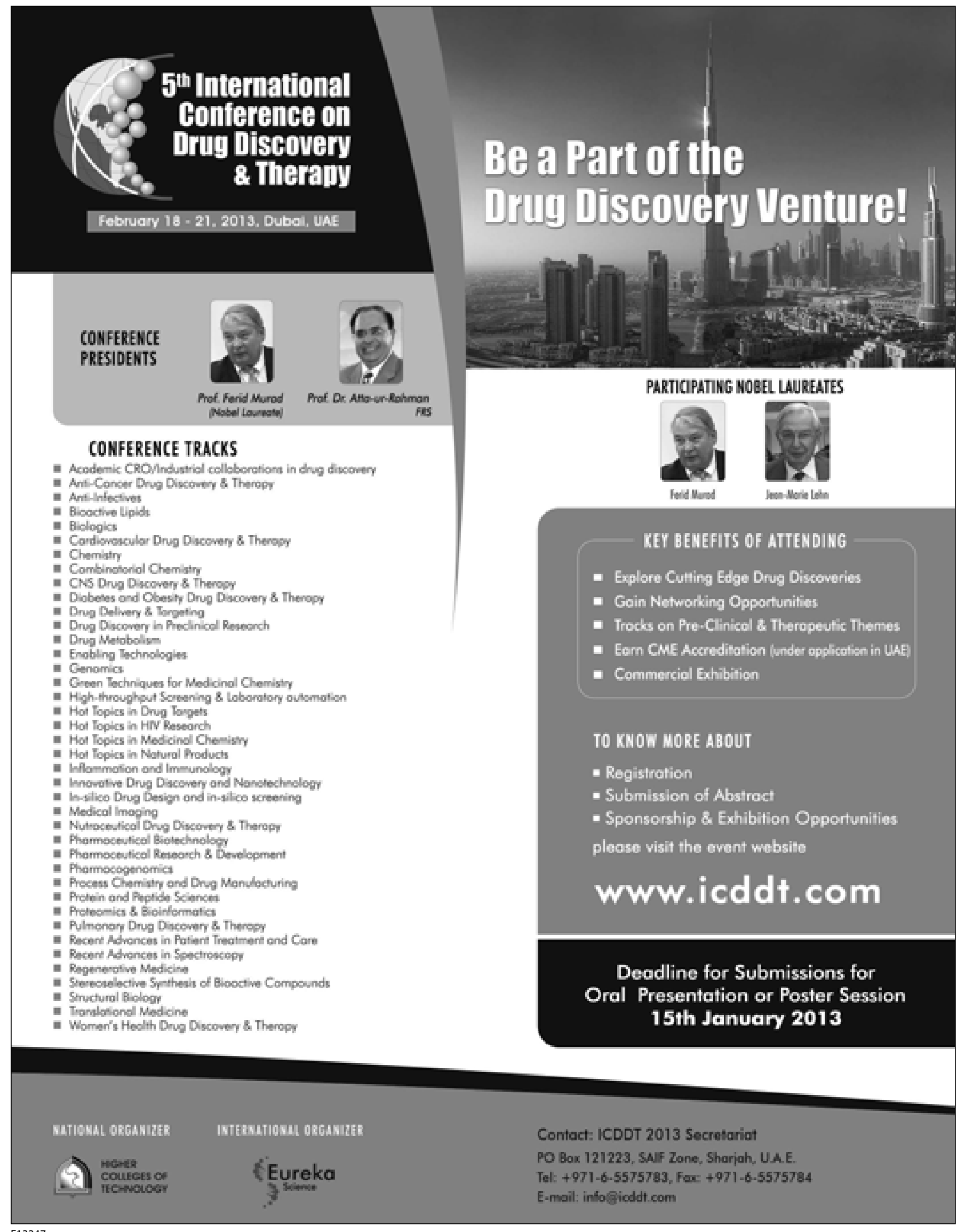




\section{WwW.bionanomed.at}

\section{APPLW
NOW!}

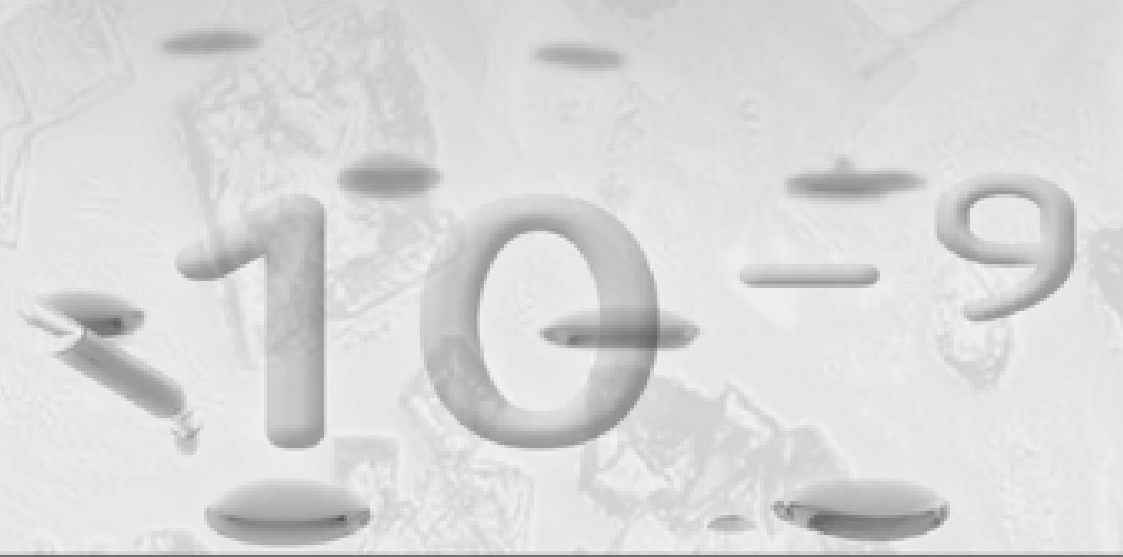

Nanotechnology enables Personalized Medicine

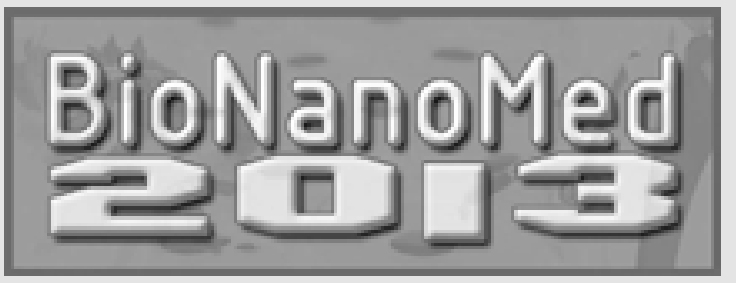

$4^{\text {th }}$ International Congress

Nanotechnology, Medicine \& Biology

13 - 15 March 2013, Krems/Austria

TOPICS

- Novel Nanomedical Solutions - Advances in Nanomedicine

- Regenerative Nanomedicine

- Nano-Bio-Technology based Diagnostics

- Nano-Bio-Technology based Therapy

Thematic Sessions

- Nano-Imaging-Technologies in Medicine

- Nanotechnology in Artificial Organ Support

- Aspects of NanoSafety

Poster Award - Exhibition - Credit Points

Deadline for oral abstracts: 14 December 2012

Deadline for Poster abstracts: 1 March 2013
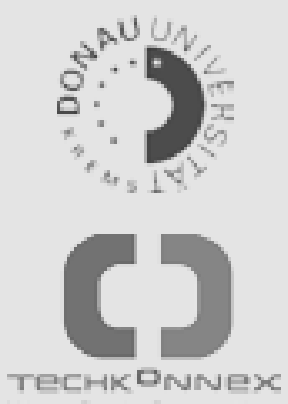
Sporting d'Hiver

Monaco

21/22 mars 2013

BIOLOGIE DU CANCER ET DU VIELLISSEMENT

CANCER DU SEIN METASTATIQUE

AGE : UN FACTEUR DE TOXICITE

UCOG-RECHERCHE CLINIQUE

LYMPHOMES AGRESSIFS

LE JOG A LU POUR VOUS

TUMEUR CEREBRALE

CANCER DE L'OVAIRE

THERAPIES CIBLEES

RADIOTHERAPIE

BIOSIMILAIRES

ANEMIE 


\section{8 \\ CONPO}

The $1^{\text {st }}$ International Congress on

\section{CONTROVERSIES IN PERSONALIZED ONCOLOGY TREATMENT}

Breast, Colon, Lung and Melanoma

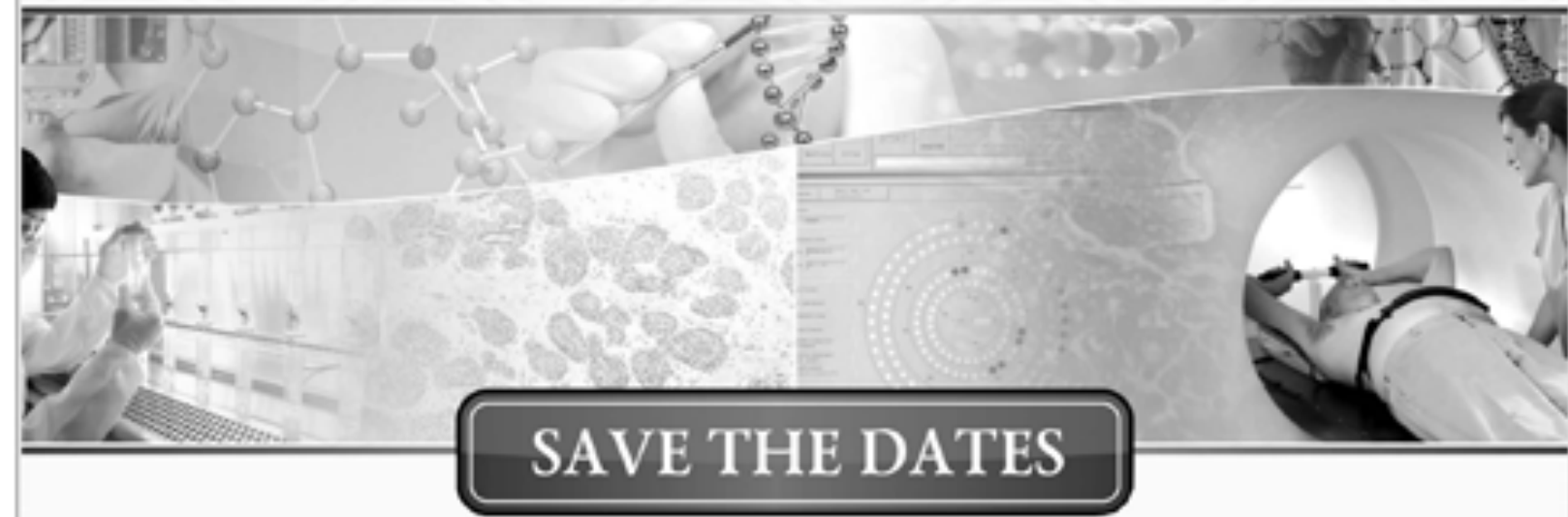

\section{MARCH 7-10, 2013 BARCELONA, SPAIN}

\section{MAIN TOPICS}

- Whole genome sequencing vs. selected genes NGS

- Epigenetic vs. Genomics

- Design clinical trial in an era of personalized oncology

- Treatment decisions based on gene mutations vs. disease origin

- Gene signatures for disease classification
- Gene signatures for disease classification

- Histopathology vs. Modern Molecular DX

- CTC as a prognostic and treatment monitoring tool

- Gene to drug development

- Small molecules vs. Abs

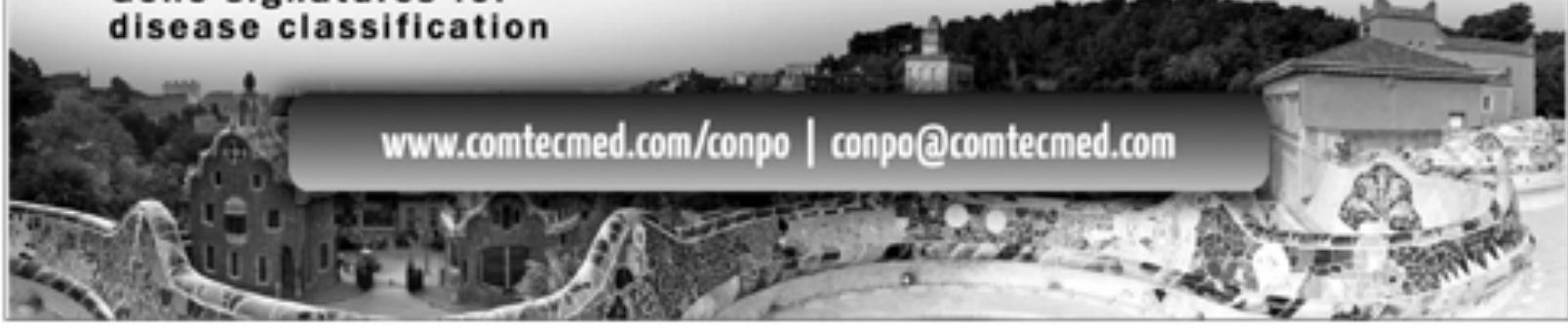




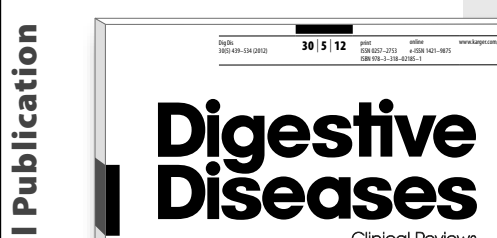 \\ (3) 0

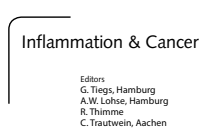

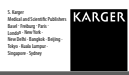

\section{Inflammation and Cancer}

\section{Editors}

G. Tiegs

A.W. Lohse

R. Thimme

C. Trautwein
Inflammation and Cancer

Editors: Tiegs, G.; Lohse, A.W. (Hamburg);

Thimme, R. (Freiburg); Trautwein, C. (Aachen)

96 p., 20 fig., 3 tab., soft cover, 2012

CHF 48.- / EUR 40.- / USD 56.00

Prices subject to change

EUR price for Germany, USD price for USA only

ISBN 978-3-318-02242-1

e-ISBN 978-3-318-02243-8

Special Topic Issue:

Digestive Diseases

Vol. 30, No. 5 (2012)

Included in subscription

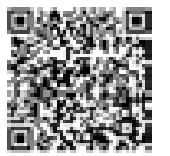

Dear Librarian

I have reviewed this publication and would like to recommend it for our library.

Recommended by:

Department:

Date:

Signature:

Orders may be placed with any bookshop,

subscription agency, directly with the publisher

or through a Karger distributor.

\section{Contents}

- Preface: Tiegs, G.

\section{Viral Hepatitis}

- Promotion of Hepatocellular Carcinoma by Hepatitis C Virus: Bühler, S.; Bartenschlager, R.

- Lymphotoxin, NF-KB, and Cancer: The Dark Side of Cytokines: Bauer, J.; Namineni, S.; Reisinger, F.; Zöller, J.; Yuan, D.; Heikenwälder, M.

\section{Immunology}

- Colitis and Colorectal Cancer: Foersch, S.; Waldner, M.J.; Neurath, M.F.

- Cellular Immune Suppressor Mechanisms in Patients with Hepatocellular Carcinoma: Zhao, F.; Korangy, F.; Greten, T.F.

- Cellular Immune Responses to Hepatocellular Carcinoma: Lessons for Immunotherapy: Schmidt, N.; Neumann-Haefelin, C.; Thimme, R.

\section{Cytokines and Intracellular Signaling}

- Interleukin-6 Trans-Signaling and Colonic Cancer Associated with Inflammatory Bowel Disease: Chalaris, A.; Schmidt-Arras, D.; Yamamoto, K.; Rose-John, S.

-TNF-Dependent Signaling Pathways in Liver Cancer: Promising Targets for Therapeutic Strategies? Roderburg, C.; Gautheron, J.; Luedde, T. -Adipocytokines and Hepatocellular Carcinoma: Wieser, V.; Moschen, A.R.; Tilg, H.

\section{Growth Factors and Regeneration}

- TGF- $\beta$ Signaling in Onset and Progression of Hepatocellular Carcinoma: Meindl-Beinker, N.M.; Matsuzaki, K.; Dooley, S.

- Epidermal Growth Factor Receptor Signaling in Hepatocellular Carcinoma: Inflammatory

Activation and a New Intracellular Regulatory

Mechanism: Berasain, C.; Nicou, A.; Garcia-Irigoyen, O.; Latasa, M.U.; Urtasun, R.; Elizalde, M.; Salis, F.; Perugorría, M.J.; Prieto, J.; Recio, J.A.; Corrales, F.J.; Avila, M.A. 
Official journal of the IAC

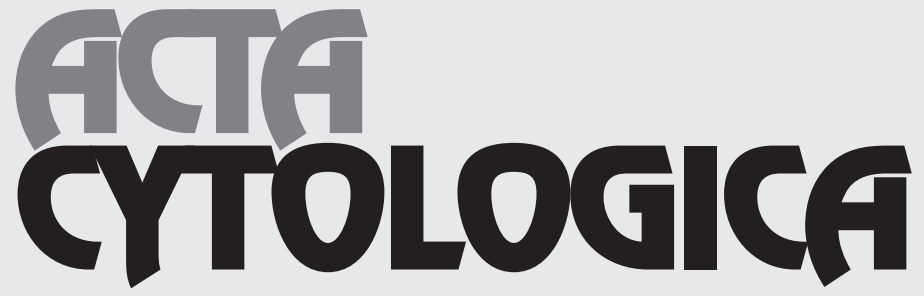

The Journal of Clinical Cytology and Cytopathology

\section{Editor-in-Cief}

Marluce Bibbo,

Philadelphia, Pa.

\section{Associate Editors}

R. Marshall Austin,

Pittsburgh, Pa.

Thomas A. Bonfiglio, Rochester, N.Y.

Lukas Bubendorf, Basel

\section{GCTOLIOAICA}

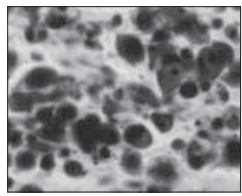

Bdmund S. Cibas,

Boston, Mass.

Yener S. Erozan,

Baltimore, Md.

David B. Kaminsky, Palm Springs, Calif.

Volker Schneider, Freiburg i.B.

Mark E. Sherman, Rockville, Md.

Diane Solomon,

Rockville, Md.

Robert Y. Osamura, Tokyo Alain P. Verhest, Brussels

Fernando C. Schmitt,

Philippe Vielh, Villejuif

Porto
More information at

\section{www.karger.com/acy}

- Pay-per-View and Subscriber Access to Full Text

- Full Table of Contents

- Full Editorial Board

- Free Abstracts and Selected Articles

- Online Sample Issue

- Submission/Guidelines for Authors

- Subscription Details

- Free Alert Service

- Online Library Recommendation

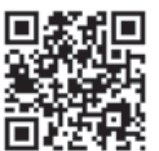

Acta Cytologica

2013: Volume 57

6 issues per volume

Language: English

ISSN 0001-5547 (print)

ISSN 1938-2650 (online)

\section{Selected contributions}

- Immunomarkers in Gynecologic Cytology: The Search for the Ideal 'Biomolecular

Papanicolaou Test': Pinto, Á.P.; Degen, M. (Boston, Mass.); Villa, L.L. (São Paulo);

(ibas, E.S. (Boston, Mass.)

- Reclassifying Formerly Indeterminate Thyroid FNAs Using the Bethesda System Reduces the Number of Inconclusive Cases: Song, J.Y.; Chu, Y.C.; Kim, L.; Park, I.S.; Han, J.Y.; Kim, J.M. (Incheon)

- Fine-Needle Cytology and Flow Cytometry Assessment of Reactive and Lymphoproliferative Processes of the Breast: Vigliar, E.; Cozzolino, I.; Fernandez, L.V.S.; Di Pietto, L.; Riccardi, A.; Picardi, M.; Pane, F.; Vetrani, A.; Troncone, G.; Zeppa, P. (Napoli)

- Ultrasound Gel Causes Fine Needle Aspiration Artifact? A Clear Choice: Royer, M.C.; Davidson, D.D.; Dimitrov, R.K. (Indianapolis, Ind.); Kuo, C.Y. (Nashville, Tenn.); Kokoska, M.S. (Indianapolis, Ind.)

- Type-Specific Human Papillomavirus DNA Detected in Atypical Glandular Cell

Pap Tests: Mulhem, E.; Amin, M.; Copeland, J.; Sharma, J.; Hunter, S. (Rochester, Mich.)

- Signet Ring Cell Carcinoma in Urine Cytology: Cytomorphologic Findings and

Differential Diagnosis: Guan, H.; Tatsas, A.D.; Ali, S.Z. (Baltimore, Md.)

- Discriminant Analysis of Malignant Mesothelioma and Reactive Mesothelium Using Three-Dimensional Nuclear Estimation: Washiya, K.; Narumi, K.; Noro, T. (Hirosaki); Hamakawa, S. (Kodaira); Furuta, N. (Tokyo); Yoshioka, H.; Watanabe, J. (Hirosaki)

- Assessment of Fine Needle Aspiration Specimen Adequacy for High-Risk HPV Detection and Genotyping in Oropharyngeal Squamous Cell Carcinoma: Solomides, C.C.; Bibbo, M.; Wang, Z.-X. (Philadelphia, Pa.)
Offering an excellent balance of articles on both clinical cytology and cytopathology, Acta Cytologica furthers the understanding of cytopathologic processes and facilitates the translation of current research into clinical practice. As the official journal of the International Academy of Cytology and affiliated to over 50 cytology societies around the world, Acta Cytologica evaluates new and existing diagnostic applications of scientific advances as well as their clinical correlation. Original papers, review articles, case reports and letters to the editor cover topics from diagnostic cytopathology, gynecologic and nongynecologic cytopathology to fine-needle aspiration, molecular techniques and diagnostic methodologies.

The perfect reference for practical use, Acta Cytologica addresses a multidisciplinary audience involved in the clinical practice of cytopathology, cell biology, oncology, interventional radiology, otorhinolaryngology, gastroenterology, urology, pulmonology and preventive medicine. 


\section{Editorial}

39 Targeted Therapies and Survival: What We Can Learn from Studies in Advanced Renal Cell Carcinoma

Procopio, G.; Verzoni, E.; de Braud, F. (Milan)

Reviews

22 New Insights into the Management of Renal Cell Cancer Pécuchet, N.; Fournier, L.S.; Oudard, S. (Paris)

43 Mammalian Target of Rapamycin as a Rational Therapeutic Target for Breast Cancer Treatment LoRusso, P.M. (Detroit, Mich.)

Clinical Studies

1 The Clinical Meaning of Intramammary Lymph Nodes Lee, S.K.; Kim, S.; Choi, M.-Y.; Kim, J.; Lee, J.; Jung, S.P.; Choe, J.-H.; Kim, J.-H.; Kim, J.S.; Kil, W.H.; Lee, J.E.; Nam, S.J. (Seoul)

6 Diarrhea Is a Positive Outcome Predictor for Sorafenib Treatment of Advanced Hepatocellular Carcinoma

Koschny, R.; Gotthardt, D.; Koehler, C.; Jaeger, D.; Stremmel, W.; Ganten, T.M. (Heidelberg)
14 Adjuvant Systemic Chemotherapy with or without Bevacizumab in Patients with Resected Liver Metastases from Colorectal Cancer

Turan, N.; Benekli, M. (Ankara); Koca, D. (Izmir);

Ustaalioglu, B.O.; Dane, F. (Istanbul); Ozdemir, N.; Ulas, A.

(Ankara); Oztop, I. (Izmir); Gumus, M.; Ozturk, M.A. (Istanbul);

Berk, V. (Kayseri); Kucukoner, M. (Diyarbakir); Uner, A.

(Ankara); Balakan, O. (Gaziantep); Helvaci, K.; Ozkan, S.

(Ankara); Yilmaz, U. (Izmir); Buyukberber, S. (Ankara) for the

Anatolian Society of Medical Oncology

32 Feasibility of Gemcitabine plus Oxaliplatin in Advanced Hepatocellular Carcinoma Patients with Child-Pugh B Cirrhosis

Dhooge, M.; Coriat, R.; Mir, O.; Perkins, G.; Brezault, C.; Boudou-Rouquette, P.; Goldwasser, F; Chaussade, S. (Paris)

57 Treatment Strategy for Superficial Pharyngeal Squamous Cell Carcinoma Synchronously Combined with Esophageal Cancer

Kaneko, K.; Yano, T.; Minashi, K.; Kojima, T.; Ito, M.; Satake, H.; Yajima, Y.; Yoda, Y.; Ikematsu, H.; Oono, Y.; Hayashi, R.; Onozawa, M.; Ohtsu, A. (Kashiwa) 